\title{
Criminology as Trends in the Development of Science
}

\author{
Dr. iur. Andrejs Vilks \\ ORCID: 0000-0002-5161-0760 \\ Andrejs.Vilks@rsu.lv \\ Dr. iur. Aldona Kipāne \\ ORCID: 0000-0001-6408-3456 \\ aldonakipane@inbox.lv \\ Rīga Stradiņš University, Faculty of Law, Latvia
}

\begin{abstract}
Criminology has a special place and is of special significance in law science. It does not always examine substantive or procedural rules and case law. The authors of the article emphasise criminology as a science of social law, the dominant object of cognition of which is socially significant phenomena (crime, drugs, corruption, prostitution, etc.), as well as the processes related to their combating and prevention.

Crime is the product of various contradictions that evolve in society, a negatively directed function of society that reflects its resulting state of moral and social "health". Dynamic social, economic, political, legal, administrative, organisational and other factors determine the constant cognition of socially undesirable and negative phenomena, improvement of research tools and approaches. Crime is transforming alongside social changes, in some cases even accelerating them. Despite the unjustified discounting of the significance of criminology as an independent science, it continues to develop. In the social science system criminology functions as a mission, creating an uncompromising attitude towards crime.

Under the current circumstances and in line with the intense invasion of modern technologies crime is taking on new forms and shapes. It successfully moves to the virtual environment, increasing its latency level and significantly complicating the magnitude and negative effects of damage detection. A new modified field of cognition of crime and its related elements a arising - digital criminology. It could play an important role in the qualitative analysis and forecasting of crime, in identifying the determinants of crime, and in determining their impact on crime. Digital methods of examination of persons,
\end{abstract}


including the use of positron emission tomography (PET) of brain scanning, would make it possible to identify persons with pronounced criminal inclinations. Digital technologies could be used in correctional institutions and establishments to help those who have served prison sentences related to deprivation of liberty, in their rehabilitation, as well as in the implementation of virtual deprivation of liberty and replacing of expensive and inefficient prisons with digital detention facilities.

Keyword: digital criminology, criminology, criminality, society.

\section{Introduction}

Implementation of appropriate values is ensured, inter alia, by the legal system, the stability of the regulatory framework, sufficient uniform application of norms and a sound legal culture in society. Much of the exercise of these functions should be ensured by the family of lawyers. Specialist sources have raised the question of the lawyer's mission. It is recognised that lawyers in the community have a special role, not only professional, but also ethical (Stradins, 2000). In essence, the mission of lawyers is to ensure justice in society. A prominent US lawyer, Roscoe Pound, has pointed out that his work is also a source of daily bread. However, the use of knowledge skills in the public interest is a major task of the profession (Pound, 1953). There is no doubt that there is need for qualitative development and application of rules that can build public confidence in the legal system (Medina \& Salinieka, 2020). Criminology and criminologists have a special place within the sub-branch of law specialisation and law.

Criminology has now occupied a prominent position in social and legal sciences. First of all, it is related to the increase of different types of potential and actual threats (including crime) or corresponding threats. As an example, we can now see that the world is facing a new socially unfavourable phenomenon, the coronavirus, which has a global impact on all spheres of civilisation, including the legal. The emergence and rapid spread of "Covid-19" may be attributed to human neglect, disregard of social and legal standards. Various views are expressed on the evolution, duration and consequences of a pandemic. High risk conditions create the most favourable soil for criminal manifestations.

Second, criminologists are highly socially active, sufficiently creative and integrative in their professional competences. The criminological approach, by studying the formation of Covid-19, its prevalence, effectiveness of its prevention measures, can provide new information and insights in mitigating the effects of the global crisis.

Third, there should be an objective need in society, especially during inclusion of the prospect of new potential criminal realities with unpredictable and also negative consequences. A physicist and writer Paolo Giordano emotionally describes the present by acknowledging that "now a time of anomaly is, and we must learn to live in it and recognise this anomaly... It is in our own interest to learn from them" (viruses) (Giordano, 2020). There should be an objective need in the society, especially in crisis and post-crisis 
periods, to model a promising model of development, taking into account new potential criminal realities that are difficult to predict, as well as negative consequences.

One of the most prominent US security experts Henry Kissinger concludes that the reality is that the post-coronavirus world will never be what it was (Kissinger, 2020). COVID-19, as a pronounced socio-epidemiological phenomenon, is undoubtedly a criminological assessment. The political and economic consequences of the coronavirus will be felt for generations to come.

\section{Crime and Criminology in the Context of Modern Dynamic Processes}

Today's rapid economic development, dynamic and highly contradictory technological processes that characterise the current global environment make demands for counter-crime one of the most pressing priorities. As Professor Vitold Zahar rightly writes: "Crime is one of the most important indicators of public social health (more precisely, the term "health"). It is a serious impediment to democracy, security and development." (Zahar, 2018). When thinking of crime, man is a being prone to dishonesty, selfishness and cruelty. Investigating personality of the offender, along with crime prevention, is one of the major trends in criminology. Man is a complex combination of biological traits that are prerequisites for individual development and as a result of which they develop under the influence of the social environment.

It should be borne in mind that in today's urbanised world, there are ultramarginalised, excluded, dominant groups (such as convicted persons; migrants, drug addicts, low-educated people, Roma people, etc.) both within and outside cities, who are predisposed to criminal behaviour. According to the Russian scientist Mikhail Gernet (Михаилл Николаевич Гернет), the main causes of crime are unemployment, poverty, unequal access to education and careers, feelings of being deprived of life (Гернет, 2005). Organised crime, terrorism, economic crime, drug criminality, trafficking in human beings, cybercrime, etc. are increasingly being seen in the international community. One must agree that "crime is a shadow of civilization. Its distribution and size therefore depend on the form and system of societal development" (Bhusal, 2009).

Crime in any society is an objectively socially driven phenomenon. Crime has always been a public concern. Ways to influence this negative social phenomenon have been sought since ancient times. Crime has become a transnational phenomenon with geopolitical and macroeconomic features, the unrestricted use of modern technology. Determinants of crime and other anti-social phenomena are not only interrelated with the sublimating resultant effect. The impact of multifactorial factors that cannot be controlled and thus prevented (unemployment, poverty and inadequate income, alcoholism, the effects of new psychoactive substances and addictive processes, etc.) should be acknowledged. As V. Tumalavičius rightly acknowledges, modern crime reflects political, economic, social and demographic tendencies of a particular era (Tumalavičius, 2016). 
Crime is the product of diverse societal contradictions, a negative function of society that reflects its resulting state of moral and social "health".

Criminology is of particular importance in the legal system, theoretical knowledge and practical fields of activity. Nowadays, it is not just a science of crime, the personality of a criminal, measures to combat and prevent it, its effectiveness. The authors join those researchers who view criminology as an independent science. It must be recognised that criminology, as a science of social justice, has undergone a difficult and complex period of evolution and development. At this stage of development, the formation of criminological thought, rooted in philosophy, theology, medical paedagogy and other sciences, can be noted.

There is still a serious debate on how to better define the concept of criminology. The content, structure and location of criminology science depend on the traditions of the criminology school, the interests of researchers, and the needs of law enforcement agencies. The authors recognise the importance of criminology in the lives of modern countries. Today, the concept of criminology is different in many countries (worldview, political, social, etc.) for various reasons or circumstances.

For example, the US and the UK are considered a part of sociology; France and Italy - at the circle of natural science. In Germany, criminology is viewed as the biosocial trend. Paul Rock, a British professor of sociology, points out that criminology is a crosscutting issue in the study of crime. Other authors, on the other hand, point out that criminology has a multidisciplinary structure dominated by crime and justice, since criminology uses the knowledge and methods of other sciences as a science of crime origin, existence and prevention (O'Brier \& Yar, 2008). David W. Garland, a professor of law and sociology at New York University, points out that one of the major opportunities for developing criminology today is the extensive (immeasurable) use of other disciplines and ideologies for new ideas. This means that a criminologist uses a variety of other disciplines, especially sociology, psychology, psychiatry, history and anthropology. The fields of biology, geography, economics, and political science, which have become directions of research, can be added to the stated disciplines (Garland, 1997).

In order to prevent the escalation of crime, it is necessary to analyse historical experiences, identify and evaluate current circumstances and look for innovative approaches. Crime research brings together a number of sciences - law, sociology, psychology and social work. One must have the courage to model the future picture of criminogenicity and anticipate ways to prevent it. Without criminological evaluation, it is difficult enough to understand many economic, political, social and other processes. When analysing the phenomenon of the "shadow" economy, it is inevitable that the segments of the criminal economy (trafficking in narcotic drugs and psychoactive substances, forced exploitation and trafficking of human beings, illicit traffic in excise goods, cybercrime, etc.) also have to be taken into account.

From a political point of view, there is the issue of buying voters' voices, manipulation of election results, malpractice in public administration and objects, and so on. 
The President of the Republic of Latvia Egils Levits has noted that ".. we have an excessive plutocracy ... when monetary power is in place of, or rather alongside, the people's power" (Levits, 2019). From a social point of view, regional and individual stratifications are crucial, which can determine criminal patterns and contribute to the motivation to obtain the necessary means of existence through criminal activity (stealing, fraud, robbery). Total deformation of values leads to weakening of the rule of law (Zahars, 2017).

\section{Criminology and Anticriminology}

The efforts and activities of criminologists to contribute to the transformation of the legal, criminal and political sphere as a whole, for a more active and effective fight against crime and other anti-social phenomena and processes, have not produced visible and considerable success. As Norwegian sociologist and criminologist Nils Christie once rightly acknowledged - crimininologists have never been sufficiently respected. Moreover, recommendations made by criminologists, often based on the results of specific studies, are often not accepted by national authorities.

There is a significant shortcoming in the development of a coherent approach, strategy and programme to reduce the harmful effects of crime and to develop mechanisms to compensate for the harm done (Christie, 2000). The question remains whether this would mean that criminologists would need to reduce their socio-political and legal activities and confine themselves to research, the production of scientific publications and academic activities. The authors' position is contrary. Criminology must evolve as a public security mission and challenge for the development and implementation of a stable and successive criminal policy. To a certain extent, this is about educating the public, increasing and intensifying its activities and applying security requirements to political authorities.

The mission of criminologists, despite the criminal passivity of the legislature and the executive, should be highly proactive. The criminological approach must be critically constructive, evaluating the current national and regional criminal justice policy, as well as developing rational and feasible projects for reduction of crime and other illegal harm. This leads to supporting Professor J. Teivāns-Treinovskis' statement that it is important to limit crime, rational use of resources, calculating the effect of crime prevention (Teivāns-Treinovskis, 2009). It is a mission and a challenge that could involve a professional approach from any field of activity; not just criminologists.

At present, it can be observed that criminology as a science of social law is gradually "excluded" from the curricula of law universities. The number of academic hours and lessons provided in the study course is reduced or the course is extended to a group of optional/free choice courses and is not taught. The justifiably valid arguments were chosen in favour of this trend: new study courses appear in the curricula (for example, "Civil and Environmental Protection", "E-Environmental Rights", "Proceedings of Administrative Liability"); or the number of credit points and lessons in traditional study 
courses ("Civil Law", "Criminal Law", "International Law") is increasing. After the restoration of independence of Latvia, the Center for Criminological Studies, established in 1993, was dissolved after ten years of successful work (in 2003). The Latvian Police Academy suffered a similar fate, where the great importance was given to educating the highly qualified officials of law enforcement authorities, including the police. The curricula included study courses on the identification, investigation and prevention of criminal offences, the study of the determinants of crime as a social phenomenon and their prevention. The LPA was liquidated in 2009. Within the institutional framework, criminological research has been carried out fragmentally and sporadically. Most criminological studies are carried out on the basis of individual research interests in the framework of doctoral dissertations: J. Alfejeva (Alfejeva, 2012); A. Feldmanis (Feldmanis, 2016); A. Kipāne (Kipāne, 2015); A. Krivin̦š (Krivin̦š, 2014); V. Voins (Voins, 2015).

However, it should be noted that, in the meantime, there is one of the greatest harms in society that causes the greatest damage - crime and criminal offences, so objectively there should be a science that studies their regularities and patterns - criminology. This science is not only related to the study of crime as a social legal phenomenon and its determinants, the personality of the offender, the mechanism of criminal offence, but also to the development of measures to reduce the harm caused by it. By its very nature, criminology as a socio-legal science has an important mission to form perceptions and assessments of crime and other anti-social phenomena in modern society, to define crime as an integral element of civilisation.

\section{Contemporary Realities and Prospects for Development of Criminology}

The technological development of modern society determines that not only stereotypes, traditions and values of the behaviour of individuals and social groups change, but also manifestations of their anti-social nature, their types and forms. This also applies to national and transnational crime. It is noted that crime paradigms are changing. The relative stability of crime and even the downward trends are very relative. If the most serious crimes (murder, robbery, extortion, rape, etc.) are not recorded with a clear upward trend, this does not mean that crime does not change qualitatively. Firstly, an invisible, the so-called latent segment of crime is growing. For various reasons victims do not submit applications to law enforcement authorities. The perception that perpetrators and criminals will not be identified often prevails. Secondly, due to the well-known features of the intellectualisation of society and the much wider use of the virtual (the Internet) environment, criminally inclined persons successfully master the digital environment. It is logical that crime is also objectively integrating into the digital environment. Criminal offences are committed not only against property or in connection with property (money laundering), but also against individuals (online sexual violence, blackmail, mobbing, etc.). Crime has successfully mastered new information and 
communication technologies and is moving into the digital environment: registering and disclosing criminal offences, conducting investigative activities by using new technologies contributed to the development of digital criminology. At Rìga Stradiňš University, they are also working on the introduction of elements of digital forensics in the relevant study courses of the Faculty of Law.

It is equally important that a new direction of criminology has been forming digital criminology. It will cover to a greater or lesser extent all elements of the subject of criminology. Even today, the state, structure and dynamics of crime are recorded in digital lines and columns. Trends in crime in general, as well as its types, regional features and peculiarities are identified. Analysis of the digital format of crime will provide opportunities for more accurate forecasting of crime, its types, places and times. The digital criminological approach is not digital criminal statistics. The use of its tools in real time will allow a sufficiently accurate determination of the time and place of new criminal offences, facilitating proactive preventive actions. So, in state of California, the USA, the police use the PredPol software, which is based on a set of incident data that is updated daily and subsequently used to determine police patrol schemes (PredPol programme).

An interesting approach on the use of digital technologies is also identification and study of predisposed persons by profiling criminals. It has already been written about the use of psycho- and neurotechnologies in the context of public safety (Vilks, 2015). Thus, it leads to the agreement with Adriana Raein that the root of the crime should be sought in a person. Early detection of sociopathological abnormalities will allow for timely individual preventive actions (Raein, 2013).

Using positron emission tomography (PET) brain scanning, in which a radioactive marker is used to study the metabolic activity of tissues, pathological segments of the brain of a person are detected, which are highly likely to predict further criminalisation of a person. The obtained data are stored and analysed in a digital format. Transparency of criminal behaviour could potentially contribute to crime prevention and rehabilitation and advance them. In addition, large-format digital data (Big Data) associated with images of people in virtual visual files is used to control the behaviour and routes of movement of these people. The monitoring mechanism is provided by a network of CCTV cameras in cities and towns and relevant databases with software in law enforcement authorities.

Using psychotechnologies, in which then data will accumulate in a digital format, will determine a more accurate profile of a person and predict people's behaviour. The relevant data can also be used in taking decisions on the employment of persons in law enforcement authorities. Experts acknowledge that the development of tools in the field of criminology would be useful in determining the length of a criminal sentence and assessing the risks due to which criminals will remain in prison or be released on the basis of predictions of personal behaviour and possible offenses in the future. 
De Montfort University in collaboration with the British Society of Criminology have identified ways to use digital technologies in correctional facilities to help those who have served prison sentences related to deprivation of liberty in their rehabilitation (What is Digital Criminology?).

In the context of digital criminology, the effectiveness of penalties and recidivism is equally important. It has been recognised that the current system of penalties of physical deprivation of liberty for serious crimes does not work. The maintenance of prisons is expensive and ineffective. Rate of repeated crimes is high. Opportunities for virtual prisons and control over the behaviour of digitised people are currently being identified. Virtual prisons, including in the homes of criminals with their usual social environment and GPS control or test calls, will undoubtedly be much cheaper than the total cost to society. The researcher T. Gash believes that prisons have no future and sentences can be carried out virtually (Gash, 2020). This direction is promising in the context of the further development of criminology.

It should be noted that in 2018, A. Powell, G. Stratton and R. Cameron published the book "Digital Criminology: Crime and Justice in Digital Society" (Powel, Stratton, Cameron, 2018). The authors focused on the research of the conceptual, legal, political and cultural framework of crime and the response to formal justice and the informal citizen-led justice movement in a global and digital society. Some studies are devoted to the development prospects, directions and practical application of digital criminology.

Criminogenic processes have a major and increasing entriopic impact on society. Studies, compilation of statistics, expert opinions show that in modern conditions: trafficking in human beings and their organs is increasing (infertility is developing); increasing cyber threats and their negative consequences; expansion of the influence of terrorist structures with new forms of violence and the emergence of "lone wolves" as elements of controlled chaos; phenomenon of drug trafficking with new synthesised psychoactive substances is becoming more widespread; immeasurable extent of the proceeds of crime affects political and social processes; illegal migration affects the demographic and social situation in a sufficient number of countries.

It should be noted that the "shadow" economy is a very significant part of the economies of many countries. These and other criminogenic entropic processes influence value systems, change perception and thinking paradigms, transform regulatory frameworks and models of governance in society, including law enforcement agencies. The mentioned and other criminogenic entropic processes have an impact on value systems, change paradigms of perception and thinking, and transform models of norms and regulations and public administration, including law enforcement authorities. 


\section{Conclucions}

The authors believe that the field of criminology is growing in the context of the criminalisation of world public relations. The help of a criminologist is needed to identify social processes, to guide the innovative process of law-making and its formation. However, criminology science in Latvia can still not be classified as a dynamically developing science. On a critical note, criminology as a branch of law remains secondary and less developed than criminal law.

Similarly, the collective monograph "Legal System of Latvia", published in 2017, which summarizes, describes and analyses fundamental questions and principles of law, does not give an idea of the science of criminology (Latvijas tiesību sistēma, 2017). The authors regret that the Latvian criminology science does not boast of systematically extensive scholarly works or collections of articles and/or crime research.

\section{Bibliography}

1. Alfejeva, J. (2012). Apdrošināšanas krāpšanas kriminoloǵiskie un krimināltiesiskie aspekti: Promocijas darbs (Eng. Criminological and criminal aspects of insurance fraud. Dissertation). Rìga: Rīgas Stradiṇa universitāte.

2. Bhusal, D. R. (2009). Economic Crime Law and Legal Practice in the context of Nepal: Dissertation. Kathmandu (Nepal).

3. Christie, N. (2000). Crime Control as Industry. Routledge.

4. Digital Forensics (2017). Norwegian University of Technology and Science. Available: https:// onlinelibrary.wiley.com/doi/pdf/10.1002/9781119262442.fmatter

5. Džordano, P. (2020). Sērgas laikā (Eng. During the plague). Rīga: Jāṇa Rozes apgāds.

6. Feldmanis, A. (2016). Policijas funkcijas noziedzības novēršanas un apkarošanas kontekstā: Promocijas darbs (Eng. Police functions in the context of crime prevention and control. Dissertation). Rīga: Rīgas Stradiṇa universitāte.

7. Garland, D. (1997). Of Crimes and Criminals: The Development of Criminology in Britain. In: Maguire, M., Morgan, R., Reiner, R. The Oxford Handbook of Criminology. Oxford [England]: Clarendon Press; New York: Oxford University Press, p. 19.

8. Gash, T. (2020). Forget prisons, the future of punishment will be virtual. Available: https://www. wired.co.uk/article/virtual-prisons.

9. Handbook of Digital Forensics and Investigation (2010). Elsevier.

10. Kissinger, H. A. (2020). The Coronavirus Pandemic Will Forever Alter the World Order. Available: https://www.wsj.com/articles/the-coronavirus-pandemic-will-forever-alter-the-worldorder-11585953005

11. Kipāne, A. (2015). Seksuālās vardarbības kriminologiiskās problēmas: Promocijas darbs (Eng. Criminological problems of sexual violence. Dissertation). Rìga: Rīgas Stradiṇa universitāte.

12. Kriviņš, A. (2014). Korupcijas novēršana un apkarošana publisko iepirkumu jomā (Eng. Preventing and combating corruption in public procurement).

13. Latvijas tiesību sistēma (Eng. Latvian legal system) (2017). Rīga: Biznesa augstskolas “Turība” izdevniecība. 
Andrejs Vilks, Aldona Kipāne. Criminology as Trends in the Development of Science

14. Levits, E. (2019). Valstsgriba (Eng. State will). Rīga, Latvijas Vēstnesis, 545 lpp.

15. Medina, L., un Salinieka, I. (2020). Kāda ir jurista misija (Eng. What is the mission of a lawyer). Jurista Vārds. Available: https://juristavards.lv/doc/275871-juridiskas-izglitibas-kvalitate-kurpejam/

16. O`Brier, M. \& Yar, M. (2008). Criminology: The Key Concepts. London and New York: Routledge.

17. Pound, R. (1953). The Lawyer from Antiquity to Modern Times: With Particular Reference to the Development of Bar Associations in the United States. St. Paul: West Publishing Company.

18. Powell, A., Stratton, G., Cameron, R. (2018). Digital Criminology: Crime and Justice in Digital Society. New York: Routledge.

19. Raein, A. (2013). Criminologist Believes Violent Behavior Is Biological. Available: https:// www.npr.org/2013/05/01/180096559/criminologist-believes-violent-behavior-isbiological?t=1595845026159

20. Stradiņš, J. (2000). Juristi un tiesiskā apziṇa mūsu sabiedrībā (Eng. Lawyers and legal awareness of our society). Latvijas Vēstnesis, Nr. 11/12, 14.01.2000. Available: https://www.vestnesis.lv/ta/ id/276

21. Teivāns-Treinovskis, J. (2009). Probācijas sistēma Latvijā: tendences, problèmas, perspektìvas. (Eng. Probation system in Latvia: tendencies, problems, perspectives). Daugavpils Universitāte: Akadēmiskais apgāds "Saule", 14. lpp.

22. Tumalavičius, V. (2016). Sabiedriskās drošības tiesiskās regulēšanas pilnveidošana globalizācijas apstākḷos: Lietuvas piemērs: Promocijas darba kopsavilkums (Eng. Improving the legal regulation of public security in the conditions of globalisation: the example of Lithuania. Summary of the Doctoral Thesis). Daugavpils Universitāte, 32.-33. lpp.

23. Vilks, A. (2015). Psiho- un neirotehnologiijas un sabiedriskās drošỉbas problēmas (Eng. Psycho and neuro technologies and public safety problems). Socrates, 1 (1). Available: doi:10.25143/ SOCR.01.2015.1.70-77

24. Voins, V. (2015). Terorisma novēršanas un apkarošanas teorētiskās un praktiskās problēmas Latvijas Republikā un Eiropas Savienībā: Promocijas darbs (Eng. Theoretical and practical problems of preventing and combating terrorism in the Republic of Latvia and the European Union. Dissertation). Rìga: Rīgas Stradiṇa universitāte.

25. What is Digital Criminology? (2018). Available: https://icpa.org/what-is-digital-criminology/

26. Zahars, V. (2017). Noziedzības ekonomiskie un sociālpsihologiskie determinanti (Eng. Economic and socio-psychological determinants of crime). Daugavpils: Daugavpils Universitātes Akadēmiskais apgāds "Saule".

27. Zahars, V. (2018). Kriminālpolitika: mūsdienu tendences un procesi. Monogrāfija (Eng. Criminal policy: modern trends and processes. Monograph). Daugavpils: Daugavpils Universitātes Akadēmiskais apgāds "Saule".

28. Gernet, M. I. (2005). Izbrannoye (Eng. The Selected). Moskva: Yusticinform. 